\title{
A Strong Positive Dendritic Effect in a Peptide Dendrimer Catalyzed Ester Hydrolysis Reaction
}

\author{
Estelle Delort, Tamis Darbre and Jean-Louis Reymond* \\ Department of Chemistry and Biochemistry, University of Berne, Freiestrasse 3, 3012 Berne, \\ Switzerland
}

Supporting Information

\section{Materials and Reagents.}

BOP reagent, Fmoc-His(Trt)-OH and Fmoc-Ser( $t \mathrm{Bu})-\mathrm{OH}$ were purchased from Senn Chemicals. Fmoc-Dap(Fmoc)-OH and Fmoc-His(Boc)-OH were purchased from BACHEM. NovaSyn ${ }^{\circledR}$ TGR resin (loading: $0.25 \mathrm{mmol} / \mathrm{g}$ ) was purchased from Novabiochem (Switzerland). All solvents used were anaytical grade. Peptide syntheses were performed manually in a glass reactor. Analytical RP-HPLC was performed in Waters (996 Photo diode array detector) chromatography system using a chromolith performance RP-18e, 4.6 x 100 $\mathrm{mm}$, flow rate $3 \mathrm{~mL} \cdot \mathrm{min}^{-1}$ column. Compounds were detected by UV absorption at $214 \mathrm{~nm}$. Preparative RP-HPLC was performed with HPLC-grade acetonitrile and MilliQ deionized water in a Waters prepak cartridge $500 \mathrm{~g}$ (RP-C18 $20 \mathrm{~mm}, 300 \AA$ pore size) installed on a Waters Prep LC4000 system from Millipore (flow rate $100 \mathrm{~mL} \cdot \mathrm{min}^{-1}$, gradient 1 or 1.25 $\left.\% \cdot \min ^{-1} \mathrm{CH}_{3} \mathrm{CN}\right)$. Fluorescence measurements were carried out with a spectraMAX fluorescence detector.

\section{General procedure for dendrimer synthesis.}

The resin (NovaSyn ${ }^{\circledR}$ TGR $\left.(0.25 \mathrm{mmol} / \mathrm{g})\right)$ was acylated with each amino acid or diamino acid ( 3 equiv) in the presence of BOP ( 3 equiv) and DIEA (5 equiv) for $30 \mathrm{~min}, 1 \mathrm{~h}$ after the first generation, $2 \mathrm{~h}$ after the second generation, $3 \mathrm{~h}$ after the third generation, $5 \mathrm{~h}$ after the fourth generation. 
Serine was used as Fmoc-Ser(tBu)-OH. Histidine was used as Fmoc-His(Trt)-OH for the synthesis of G1 and G2, as Fmoc-His(Boc)-OH for the synthesis of G3 and G4.

After each coupling the resin was successively washed with DMF, $\mathrm{MeOH}$, and $\mathrm{CH}_{2} \mathrm{Cl}_{2}(2 \times$ with each solvent), then checked for free amino groups with the 2,4,6-trinitrobenzenesulfonic acid test. The coupling was repeated if free amines were still present.

The Fmoc protecting group was removed with a solution of $20 \%$ piperidine in DMF $(2 \times 10$ min) and the solvent was then removed by filtration. At the end of the synthesis, the resin was acylated with acetic anhydride/ $\mathrm{CH}_{2} \mathrm{Cl}_{2}(1: 1)$ for $1 \mathrm{~h}$. The resin was dried and the cleavage was carried out with TFA/anisole/1,2-ethanedithiol/ $\mathrm{H}_{2} \mathrm{O}(93: 5: 1: 1)$ for $4 \mathrm{~h}$. The peptide was precipitated with methyl tert-butyl ether then dissolved in a water/acetonitrile mixture. All dendrimers were purified by preparative HPLC (flow rate of $100 \mathrm{mLmin}^{-1}$; column: Waters prepak cartridge $500 \mathrm{~g}$ RP-C18, $20 \mathrm{~mm}$, pore size: $300 \AA$, detection: $\lambda=214 \mathrm{~nm}$ ).

$\mathrm{A}=0.1 \%$ TFA in $\mathrm{H}_{2} \mathrm{O} ; \mathrm{B}=60 \% \mathrm{H}_{2} \mathrm{O}, 40 \% \mathrm{CH}_{3} \mathrm{CN}, 0.1 \%$ TFA.

Dendrimer G1. Starting with $100 \mathrm{mg}$ of NovaSyn ${ }^{\circledR}$ TGR resin $(0.25 \mathrm{mmol} / \mathrm{g})$, the sequence ((Ac-His-Ser $)_{2}$ Dap-His-Ser)- $\mathrm{NH}_{2}$ was obtained as colorless foamy solid after preparative RPHPLC purification (3.3 mg, $15 \%)$.

Preparative RP-HPLC $: t_{\mathrm{R}}=10 \mathrm{~min}$. (A/B $=100 / 0$ to $\mathrm{A} / \mathrm{B}=50 / 50$ in 40 minutes); analytical RP-HPLC $: t_{\mathrm{R}}=2.785 \min (\mathrm{A} / \mathrm{B}=100 / 0$ to $\mathrm{A} / \mathrm{B}=50 / 50$ in 10 minutes $) ; \mathrm{ESI}^{+} \mathrm{MS}, \mathrm{CH}_{3} \mathrm{CN}$ : calcd for $\mathrm{C}_{34} \mathrm{H}_{49} \mathrm{~N}_{15} \mathrm{O}_{12}[\mathrm{M}+\mathrm{H}]^{+}$: 859.37 , found: 859.38 .

Dendrimer G2. Starting with $100 \mathrm{mg}$ of NovaSyn ${ }^{\circledR}$ TGR resin $(0.25 \mathrm{mmol} / \mathrm{g})$, the sequence ((Ac-His-Ser $)_{2}$ Dap-His-Ser $)_{2}$ Dap-His-SerNH $\mathrm{H}_{2}$ was obtained as colorless foamy solid after preparative RP-HPLC purification $(21.9 \mathrm{mg}, 44 \%)$.

Preparative RP-HPLC $: t_{\mathrm{R}}=14 \min (\mathrm{A} / \mathrm{B}=100 / 0$ to $\mathrm{A} / \mathrm{B}=50 / 50$ in 40 minutes $)$; analytical RP-HPLC $: t_{\mathrm{R}}=3.272 \min (\mathrm{A} / \mathrm{B}=100 / 0$ to $\mathrm{A} / \mathrm{B}=50 / 50$ in 10 minutes $) ; \mathrm{ESI}^{+} \mathrm{MS}, \mathrm{CH}_{3} \mathrm{CN}$ : calcd for $\mathrm{C}_{80} \mathrm{H}_{113} \mathrm{~N}_{35} \mathrm{O}_{28}[\mathrm{M}+\mathrm{H}]^{+}$: 2011.85, found: 2012.25 . 
Dendrimer G3. Starting with $200 \mathrm{mg}$ of NovaSyn TGR resin $(0.25 \mathrm{mmol} / \mathrm{g})$, the sequence $\left(\left((\text { His-Ser })_{2} \text { Dap-His-Ser }\right)_{2} \text { Dap-His-Ser }\right)_{2}$ Dap-His-SerNH $\mathrm{N}_{2}$ was prepared. Half of the resin was acetylated and the product cleaved from the resin and purified by preparative HPLC to give dendrimer $\mathbf{G 3}$ as colorless foamy solid (34.2 mg, $32 \%)$.

Preparative RP-HPLC: $t_{\mathrm{R}}=18 \mathrm{~min}(\mathrm{~A} / \mathrm{B}=100 / 0$ to $\mathrm{A} / \mathrm{B}=50 / 50$ in 40 minutes $)$; analytical RP-HPLC $: t_{\mathrm{R}}=5.303 \mathrm{~min}(\mathrm{~A} / \mathrm{B}=100 / 0$ to $\mathrm{A} / \mathrm{B}=50 / 50$ in 10 minutes $) ; \mathrm{ESI}^{+} \mathrm{MS}, \mathrm{CH}_{3} \mathrm{CN}$ : calcd for $\mathrm{C}_{172} \mathrm{H}_{241} \mathrm{~N}_{75} \mathrm{O}_{60}[\mathrm{M}+\mathrm{H}]^{+}$: 4316.81, found: 4318.13 .

Dendrimer G4. The remaining half of NovaSyn TGR resin $(0.25 \mathrm{mmol} / \mathrm{g})$ from the G3 synthesis above was deprotected and coupled further with Dap, Ser, and His to grow the fourth generation, and finally $\mathrm{N}$-acetylated to give the final sequence $\left(\left(\left((\text { Ac-His-Ser })_{2}\right.\right.\right.$ DapHis-Ser $)_{2}$ Dap-His-Ser ${ }_{2}$ Dap-His-Ser ${ }_{2}$ Dap-His-SerNH ${ }_{2}$. Cleavage and preparative RP-HPLC purification was then performed. Collecting fractions 8-11 of the main peak (see data below), which eluted first, gave dendrimer G4 as colorless foamy solid (10.4 mg, $4.6 \%)$. Later fractions 12-14 were analyzed and showed contamination with a sequence lacking one HisSer pair.

Preparative RP-HPLC $: t_{\mathrm{R}}=15 \min (\mathrm{A} / \mathrm{B}=90 / 10$ to $\mathrm{A} / \mathrm{B}=50 / 50$ in 40 minutes $)$; analytical RP-HPLC $: t_{\mathrm{R}}=5.871 \mathrm{~min}(\mathrm{~A} / \mathrm{B}=100 / 0$ to $\mathrm{A} / \mathrm{B}=50 / 50$ in 10 minutes $) ; \mathrm{ESI}^{+} \mathrm{MS}, \mathrm{CH}_{3} \mathrm{CN}$ : calcd for $\mathrm{C}_{356} \mathrm{H}_{497} \mathrm{~N}_{155} \mathrm{O}_{124}[\mathrm{M}+\mathrm{H}]^{+}$: 8926.73, found: 8929.25.

\section{Kinetic measurements}

The kinetic measurements were carried out by using a SPECTRAMax fluorescence plate reader $\left(\lambda_{\mathrm{ex}}=460 \mathrm{~nm}, \lambda_{\mathrm{em}}=530 \mathrm{~nm}\right)$ at $26.5^{\circ} \mathrm{C}$. Assays were followed in individual wells of round-bottom polystyrene 96-well-plates (Costar). Kinetic experiments were typically followed for 2-12 $\mathrm{h}$. The dendrimers were stored at $-20{ }^{\circ} \mathrm{C}$ in $1 \mathrm{mM}$ stock solution in $\mathrm{B}$ (acetonitrile/water: 1/1). Dendrimer stock solutions were freshly diluted in citrate buffer (pH 5.5, $5 \mathrm{mM}$ ) to the final concentrations: $\mathbf{G 1}$ to $0.106 \mathrm{mM}, \mathbf{G} 2$ to $0.064 \mathrm{mM}, \mathbf{G 3}$ to $0.0355 \mathrm{mM}$, 
G4 to $0.0188 \mathrm{mM}$. The buffer was freshly prepared using MilliQ deionized water, the $\mathrm{pH}$ being adjusted with aqueous $1 \mathrm{~N} \mathrm{NaOH}$ and aqueous $1 \mathrm{~N} \mathrm{HCl}$ solutions.

Initial reaction rates were calculated from the steepest part observed during the first $1000 \mathrm{~s}$ of each curve. In a typical experiment, $20 \mu \mathrm{L}$ of citrate buffer (pH 5.5, $5 \mathrm{mM}$ ) were first added in a well, then $2.5 \mu \mathrm{L}$ of a dendrimer solution $(0.106 \mathrm{mM} \mathrm{G1,} 0.064 \mathrm{mM} \mathrm{G2}, 0.0355 \mathrm{mM} \mathrm{G3}$, $0.0188 \mathrm{mM}$ G4 in citrate buffer $(\mathrm{pH} 5.5,5 \mathrm{mM})$, concentration in the well: $10.6 \mu \mathrm{M}$ G1, 6.40 $\mu \mathrm{M}$ G2, $3.55 \mu \mathrm{M} \mathrm{G3}, 1.88 \mu \mathrm{M}$ G4) and last $2.5 \mu \mathrm{L}$ of substrate solution $(2 \mathrm{mM}$ in acetonitrile/water 1/1, final concentration in the well: $200 \mu \mathrm{M})$. Fluorescence data were converted to product concentration by means of a calibration curve with pure product 5 which was linear in the concentration range used. (Calibration curves were obtained by measuring the fluorescence of $22.5 \mu \mathrm{L}$ aqueous buffer and $2.5 \mu \mathrm{L}$ of solution of $10,20,40,60,80,100$, 200, 300, 400, 500, 800, $1000 \mu \mathrm{M}$ HPTS 5).

Michaelis-Menten parameters were obtained from the linear double reciprocal plot of $1 / V_{\text {net }}$ $\left(V_{\text {net }}=V_{\text {app }}-V_{\text {uncat }} v s .1 /[\mathrm{S}]\right.$ measured with (final concentrations) $10.6 \mu \mathrm{M}$ G1, $6.4 \mu \mathrm{M} \mathrm{G2}$,

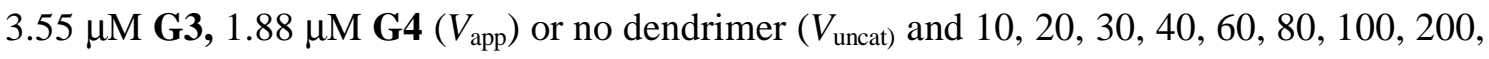
$400 \mu \mathrm{M}$ substrate (and eventually 600, 800 and $1000 \mu \mathrm{M}$ substrate for the most active dendrimers having very low $K_{\mathrm{M}}$ ) in $5 \mathrm{mM}$ citrate $\mathrm{pH}$ 5.5. The catalytic rate constants $k_{\text {cat }}$ were calculated from the steepest part observed during the first $1000 \mathrm{~s}$ of each curve. The catalytic rate constant $k_{\text {cat }}$ for the hydrolysis is given by $k_{\text {cat }}=V_{\max } /[\mathrm{D}]$, where [D] indicates the concentration of dendrimers. The rate constants $k_{\text {uncat }}$ without catalyst were calculated from the part observed during the first $4000 \mathrm{~s}$ of each curve. Kinetic parameters such as maximum velocity $\left(V_{\max }\right)$ and Michaelis constant $\left(K_{\mathrm{M}}\right)$ were determined by the least squares method from a Lineweaver-Burk plot. The reaction rate with 4-methylimidazole (4-Me-Im) was obtained under the same conditions with 40, 60, 80, 100, 200, 300, 400, 500, 800, $1000 \mu \mathrm{M} 4$ - 
Me-Im and $200 \mu \mathrm{M}$ substrate in citrate buffer $(\mathrm{pH} \mathrm{5.5,5} \mathrm{mM})$. The second order rate constants $k_{2}$ were calculated from linear regression of the experimentally measured pseudo first order rate constants k' as a function of 4-Me-Im concentrations.

For the $\mathrm{pH}$ profile the following buffers were prepared: Citrate $\mathrm{pH} 4.6(20 \mathrm{mM}), \mathrm{MES} \mathrm{pH} 5.0$ (20 mM), MES pH $5.6(20 \mathrm{mM})$, BisTris buffer pH $6.0(20 \mathrm{mM})$, BisTris buffer pH 6.5 (20 mM), HEPES pH $7.6(20 \mathrm{mM})$. They were freshly prepared using MilliQ deionized water, the $\mathrm{pH}$ being adjusted with aqueous $1 \mathrm{~N} \mathrm{NaOH}$ and aqueous $1 \mathrm{~N} \mathrm{HCl}$ solutions.

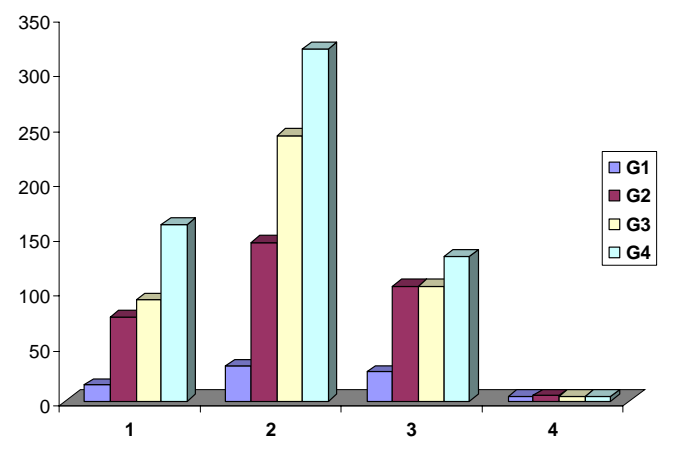

Figure S1. Apparent rate acceleration $V_{\text {net }} / V_{\text {uncat }}$ observed with 1, 2, 3, 4 = $200 \mu \mathrm{M}$ and $\mathbf{G 1}=10.6 \mu \mathrm{M}, \mathbf{G} 2=6.4 \mu \mathrm{M}, \mathbf{G 3}=3.55 \mu \mathrm{M}, \mathbf{G} 4=1.88 \mu \mathrm{M}$ in aq. $5 \mathrm{mM}$ citrate $\mathrm{pH} 5.5,26^{\circ} \mathrm{C}$.

\section{Isothermal Calorimetry measurements.}

ITC experiments with Omega Ultrasensitive Isothermal Titration Calorimeter (MicroCal Inc.). All solutions were freshly prepared and degassed with a nitrogen flux for 20 minutes. The cell was filled through a $2.5 \mathrm{ml}$ glass filling syringue with a dendrimer solution in aqueous buffer with the following concentrations: G1 $0.5 \mathrm{mM}$, G2 $0.4 \mathrm{mM}, \mathbf{G 3} 0.2 \mathrm{mM}$, G4 $0.05 \mathrm{mM}$ in aqueous buffer. A $250 \mu \mathrm{l}$ injection syringue with a stir paddle was filled with a $10 \mathrm{mM}$ solution of substrate $\mathbf{5}$ or product $\mathbf{4}$ in the same aqueous buffer. After the equilibration of the cells, each experiment consisted of 20 injections of $10 \mu \mathrm{l}$, with 180 seconds between two injections. Sample stirring was set at $400 \mathrm{rpm}$ for all measurements, and the temperature was set as $300 \pm 0.3 \mathrm{~K}$. A background titration, consisting of the identical titrant solution but only 
the buffer solution in the sample cell, was subtracted from each experimental titration to account for heat of dilution. ITC data were analyzed with ORIGIN software. After subtracting the reference the raw data were integrated and normalized resulting in a plot of $\Delta \mathrm{H}$ per moles of injectant versus molar ratio. Data were fit to a single-site binding to obtain $\Delta \mathrm{H}, K_{\mathrm{a}}$ and $n$ under each condition. 


\section{G1 crude}

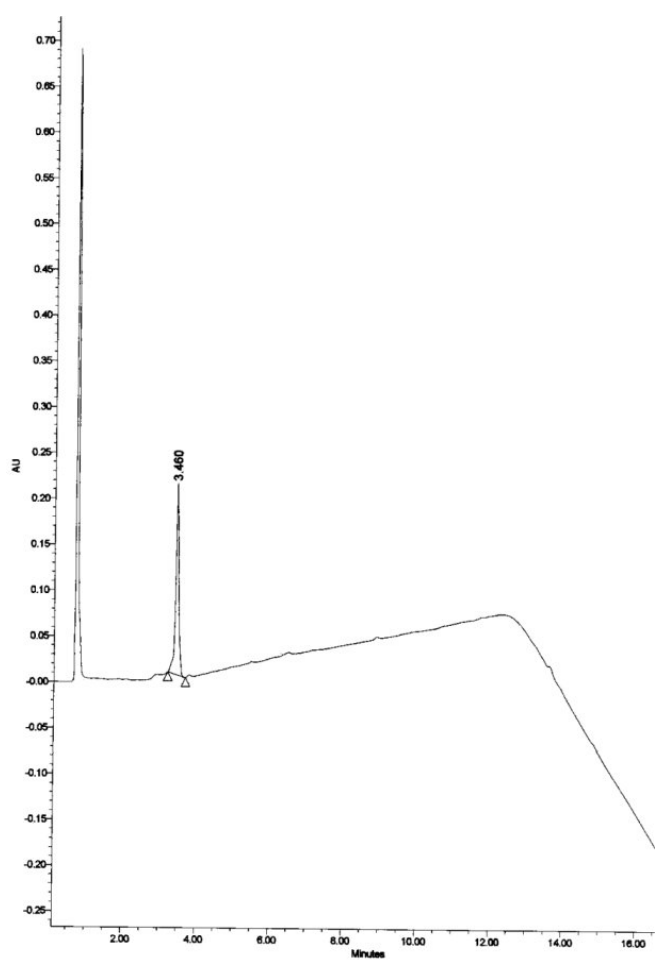

G1

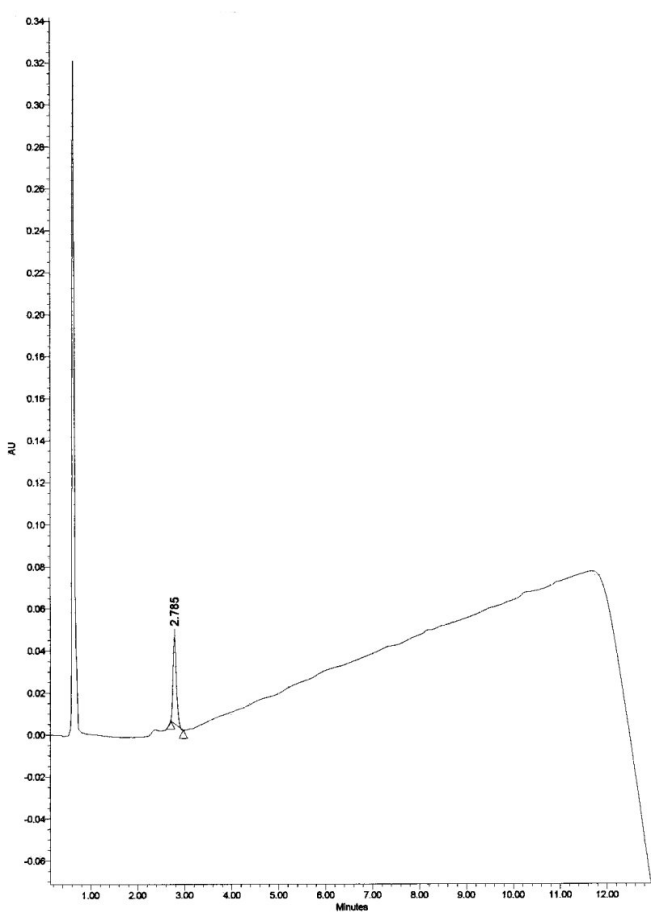

$\lambda=214 \mathrm{~nm}, \mathrm{~A} / \mathrm{B}=100 / 0$ to $\mathrm{A} / \mathrm{B}=50 / 50$ in 10 minutes $\lambda=214 \mathrm{~nm}, \mathrm{~A} / \mathrm{B}=100 / 0$ to $\mathrm{A} / \mathrm{B}=50 / 50$ in 10 minutes

\section{G1}

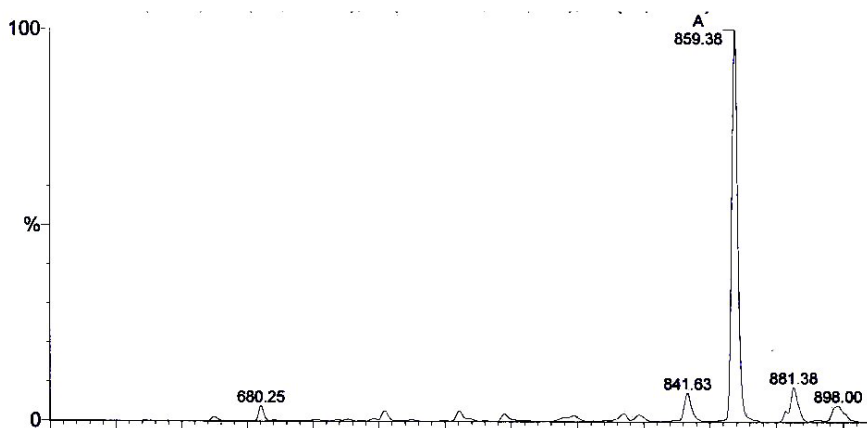




\section{G2 crude}

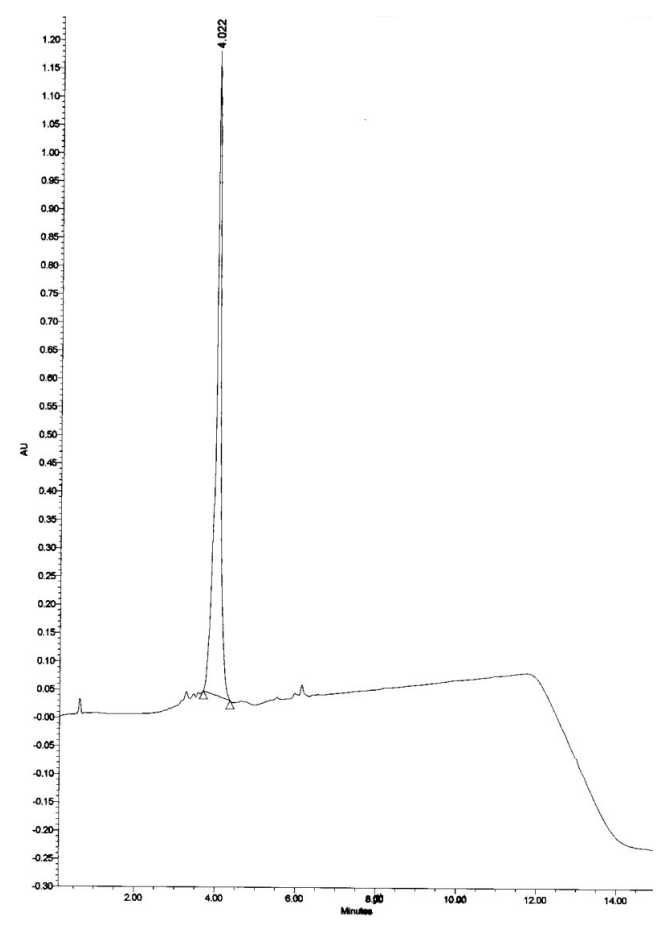

G2

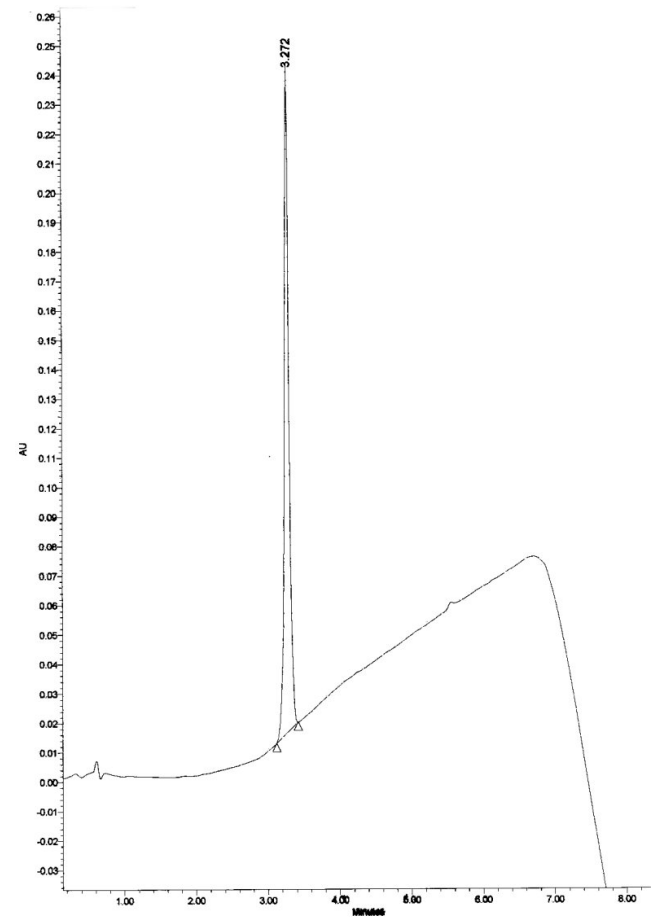

$\lambda=214 \mathrm{~nm}, \mathrm{~A} / \mathrm{B}=100 / 0$ to $\mathrm{A} / \mathrm{B}=50 / 50$ in 10 minutes $\lambda=214 \mathrm{~nm}, \mathrm{~A} / \mathrm{B}=100 / 0$ to $\mathrm{A} / \mathrm{B}=50 / 50$ in 10 minutes

\section{G2}

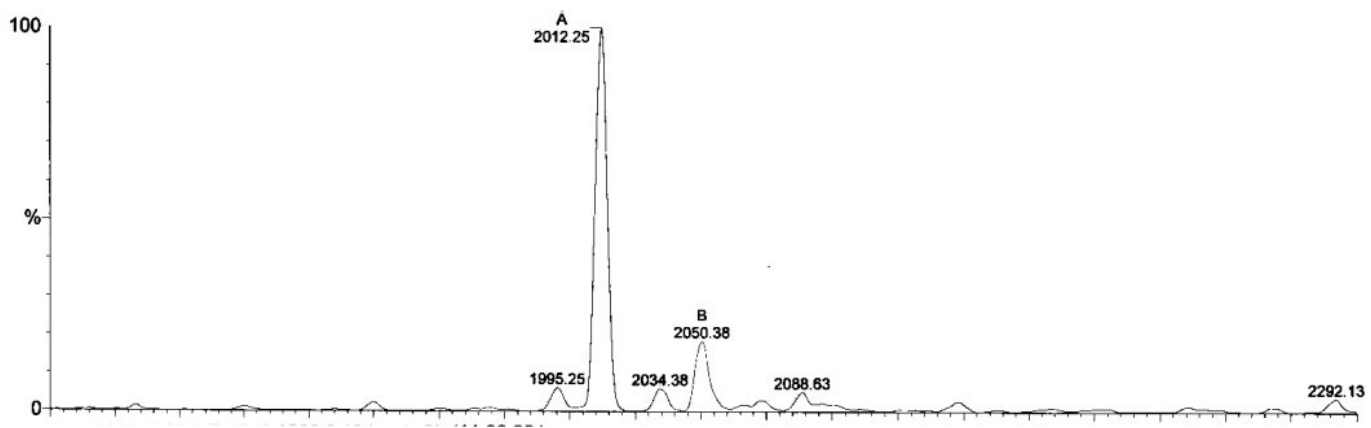


G3 crude

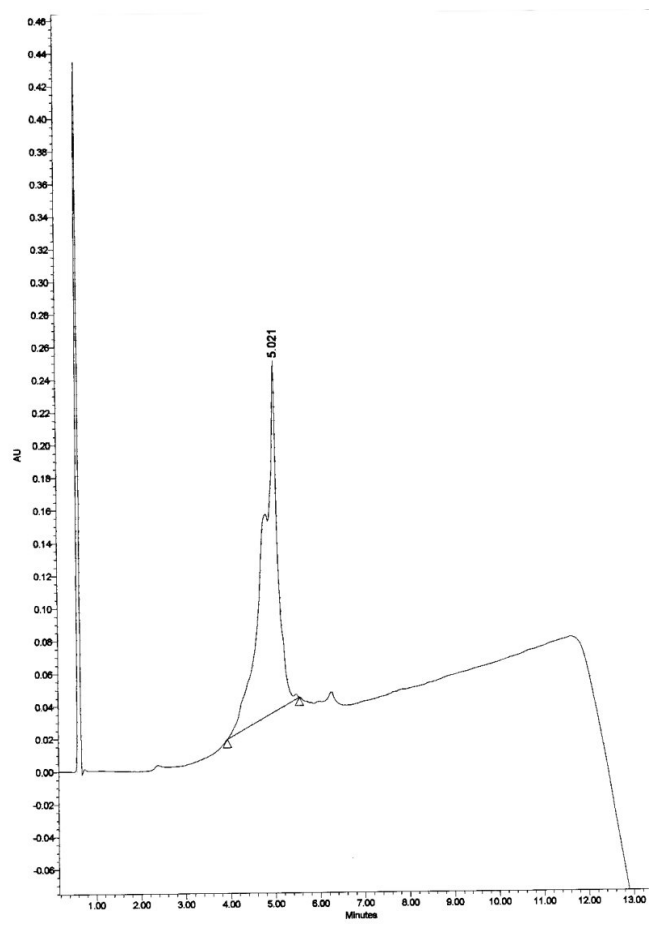

$\lambda=214 \mathrm{~nm}, \mathrm{~A} / \mathrm{B}=100 / 0$ to $\mathrm{A} / \mathrm{B}=50 / 50$ in 10 minutes $\lambda=214 \mathrm{~nm}, \mathrm{~A} / \mathrm{B}=100 / 0$ to $\mathrm{A} / \mathrm{B}=50 / 50$ in 10 minutes

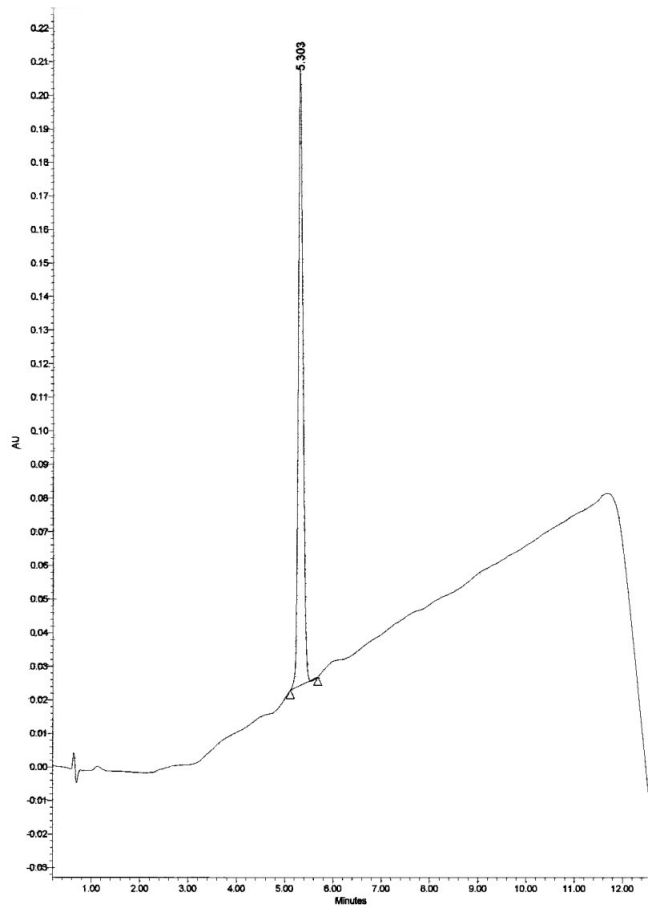

\section{G3}

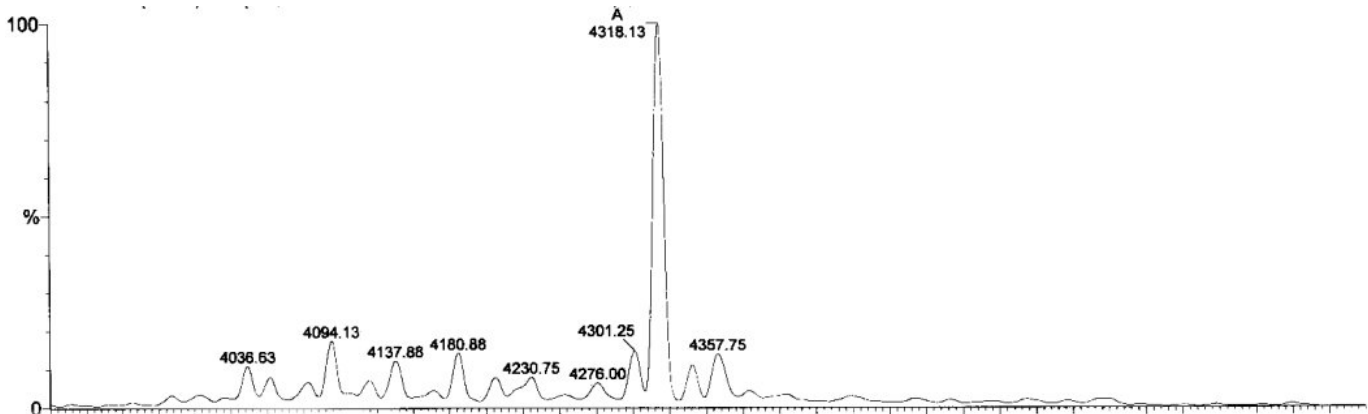




\section{G4 crude}

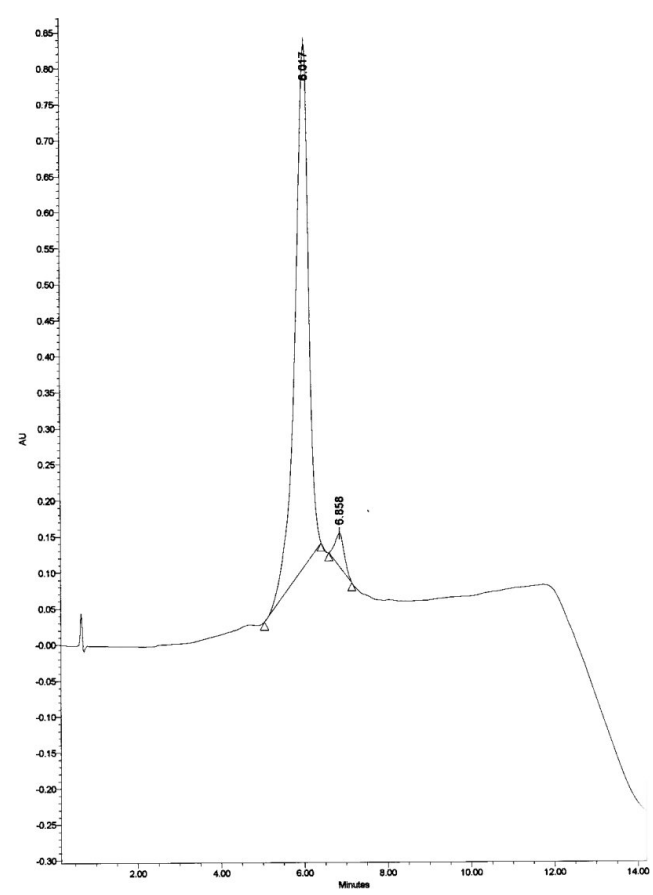

$\lambda=214 \mathrm{~nm}, \mathrm{~A} / \mathrm{B}=100 / 0$ to $\mathrm{A} / \mathrm{B}=50 / 50$ in 10 minutes

\section{G4: Preparative HPLC}

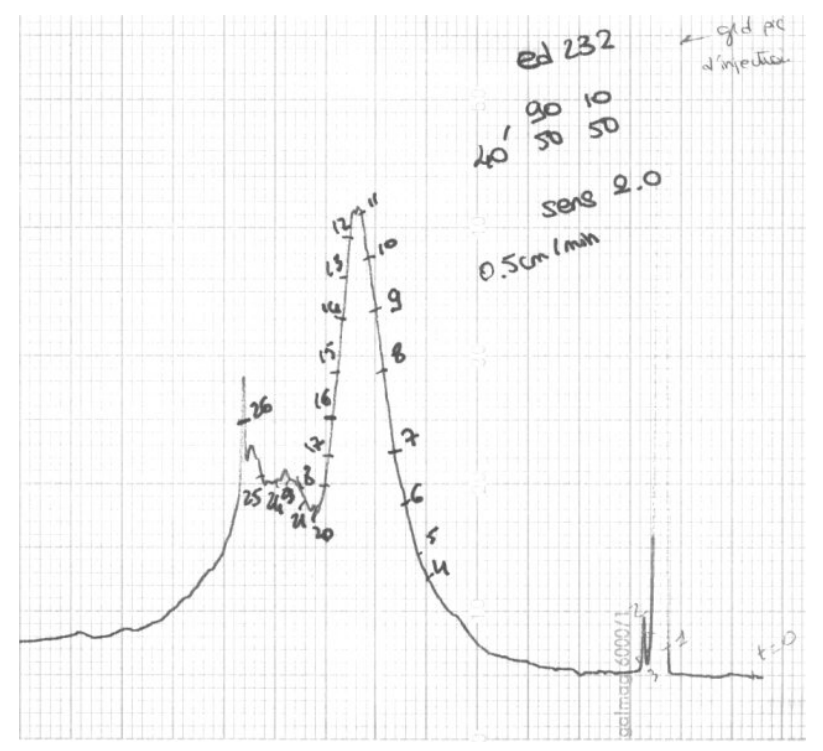

$\lambda=214 \mathrm{~nm}, \mathrm{~A} / \mathrm{B}=900 / 1$ to $\mathrm{A} / \mathrm{B}=50 / 50$ in 40 minutes 


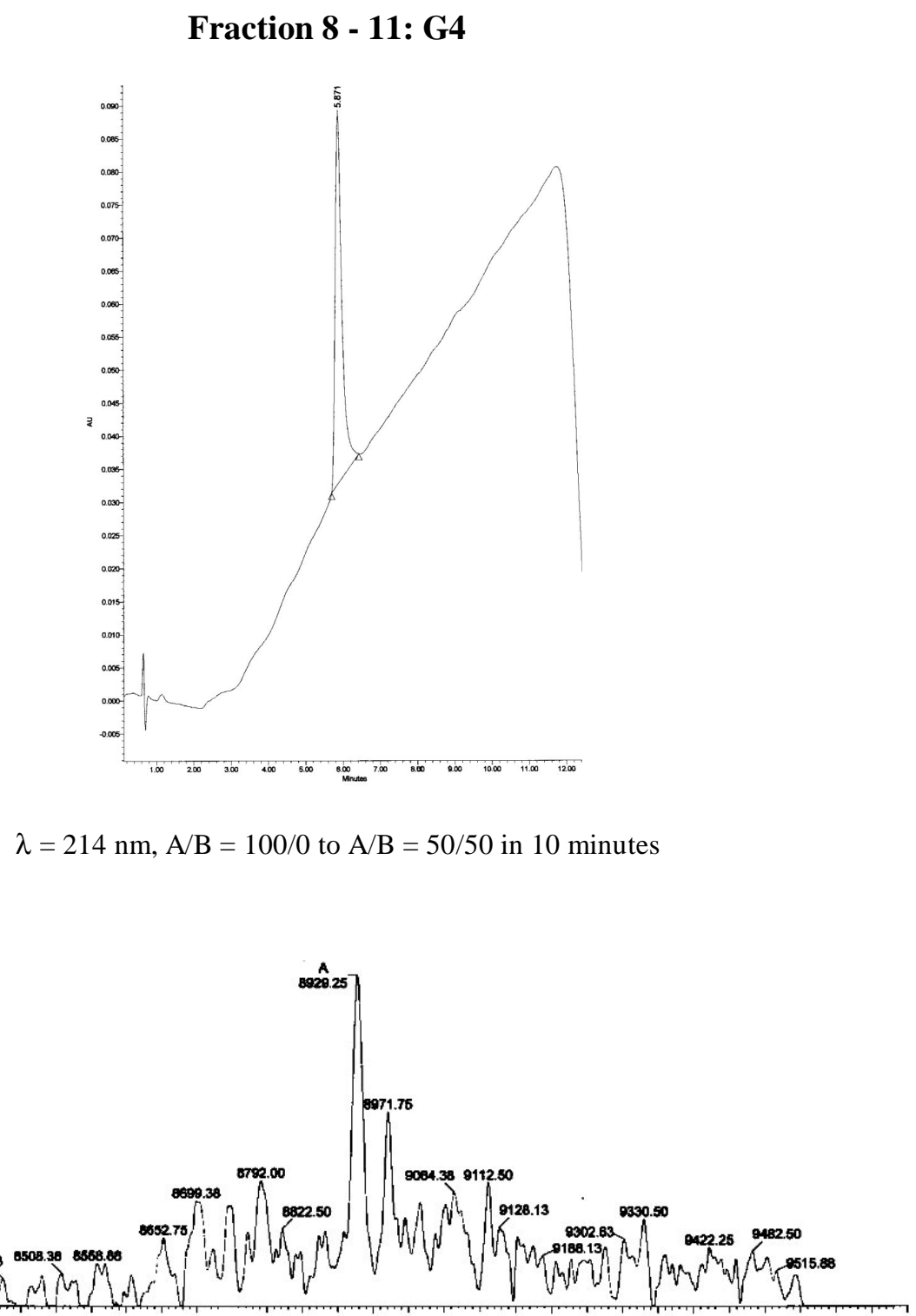

Fractions 12 - 14 : G4 and presence of the deleted dendrimer G4 - His-Ser

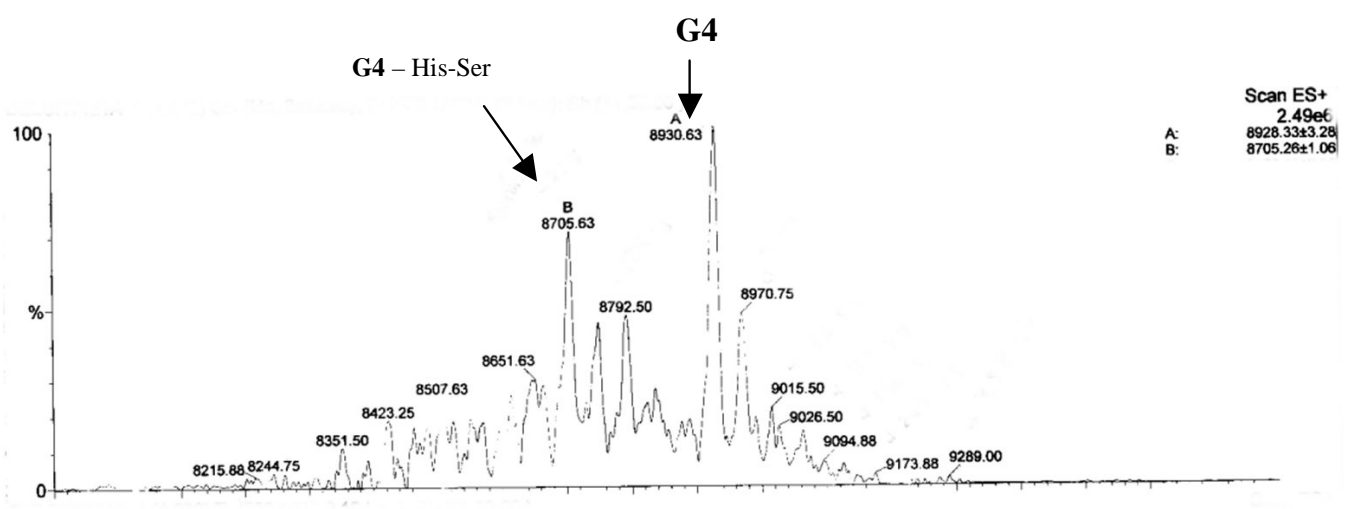

